\title{
GREATER EURASIAN PARTNERSHIP: ECONOMIC PERSPECTIVES OF INTEGRATION WITH THE EAEU
}

\author{
A. V. IVANTSOV \\ Academy of Public Administration under the Aegis \\ of the President of the Republic of Belarus
}

\begin{abstract}
This article analyzes the current state and future prospects of integration associations and formats of multilateral economic cooperation from the point of view of the implementation of the Comprehensive Eurasian Partnership initiative. The author analyzes the role of this initiative as an instrument of Russian politics and assesses its potential for strengthening international cooperation in Eurasia. In particular, it analyzes the possibilities of harmonizing key projects and initiatives within the EAEU. The work examines the potential of the largest multilateral formats in Eurasia as in the economic sphere - the Comprehensive Regional Economic Partnership, the Belt and Road Initiative, the Eurasian Economic Union, etc. to multilateral economic projects in Eurasia as a locomotive for promoting strategic interests, as well as realizing the potential of the EAEU.

It is concluded that institutional overload is observed in the economic sphere of Greater Eurasia, caused by the existence of a number of parallel developments of integration initiatives and mechanisms of economic cooperation. Based on the foregoing, the strengthening of the EAEU as the institutional core of Greater Eurasia can become the basis for the formation of a regulatory mega-space. However, the aggregate economic potential of the EAEU member states does not allow the Union to be the largest economic pole and a leading center for the development of multilateral institutions in Greater Eurasia. It is assumed that the solution to this problem could be the development of the Comprehensive Eurasian Partnership towards the conjugation of the EAEU and RCEP - the largest format for developing rules for international economic interaction in Asia and formulating specific proposals for building a system of mutually beneficial relations between the largest players of Eurasia, in which all interested states will be involved on mutually beneficial terms to strengthen international cooperation.
\end{abstract}

Key words: Greater Eurasian Partnership; EAEU; EU; RCEP; Eurasia; integration; "One Belt, One Road"; Shanghai Cooperation Organization.

For citations: Ivantsov A. V. (2021). Greater Eurasian Partnership: economic perspectives of integration with the EAEU. In: Actual problems of international relations and global development: collection of scientific papers. Minsk. Vol. 9, p. 303312. https://doi.org/10.33581/2311-9470-2021-9-303-312 
Introduction. The appearance of mega regional initiatives put forward by the leading players of the continent is observed in Eurasia. In 2011 the US State Department considered the New Silk Road concept as an attempt to strengthen trade and economic integration between Afghanistan, Central Asia, Pakistan and India, and the North-South Silk Road "as an addition to East-West ties in Eurasia" [1, pp. 8-19]. China has its own initiatives such as "One Belt One Road" Initiative, which is aimed at unifying regional efforts in the field of infrastructure construction, as well as Japan has its "Partnership in the creation of high-quality infrastructure" initiated by the Shinzo Abe cabinet [2].

The main objective of this article is to analyze the prospects for the creation of the Greater Eurasian Partnership, identify problems and outline the perspectives of the further format of cooperation.

The chronological framework of the study covers the period from the second half of the XX century to the present day.

Research methods. When writing the article, methods of international relations research such as content analysis and event analysis, as well as historical and descriptive ones were used.

Literature review. The major sources for the analysis of the problem were the works devoted to the shaping of Eurasian cooperation, the Chinese initiative "One Belt One Road", their role and place in regional cooperation. Among the sources are scientific articles written by such scholars as M. Glyants, S. Yu. Glazieva, D. P. Novikova, J. Nye, R. Keohane, K. Waltz and others.

Research results. The idea of creation of the Greater Eurasian Partnership was formulated by Vladimir Putin on December 3, 2015 during his appeal to the Federal Assembly of the Russian Federation: “...Together with my EAEU colleagues I suggest to start a dialogue on the creation of a possible economic partnership with the SCO and ASEAN members, as well as with the states that are joining the SCO. Jointly our states make up almost a third of the world economy in terms of purchasing power parity. At an early stage, this partnership could focus on the protection of investments, optimization of procedures for the movement of goods across borders, joint development of technical standards for products of the next technological generation, as well as on mutual access to the services and capital markets. It is only natural that this partnership should be based on the principles of equality and consideration of mutual interests ..." [3].

The Greater Eurasian Partnership (GEP) is a network of dialogues between Eurasian key players not only from the largest national econo- 
mies, but also from regional economic associations including non-formal groupings and initiatives such as China's "One Belt One Road" Initiative (OBOR), the Northern Sea Route, the Trans-Siberian Railway, etc.

In academic literature, there is a strong opinion, reflected both in liberal theories and concepts, and in many authors' works of the tradition of realism, that claims creation and development of institutions serve to strengthen international system by developing trust between states [4, pp.329-349], or by stabilizing distribution of forces and statuses within international hierarchies [5]. Special attention is paid to the stimulating role of educational centers and norms in the development of economic relations between states and increasing interdependence between them, which allows to speak about the predominantly positive role of almost any institution-building for strengthening political and economic ties between states.

Nowadays a dozen and a half regional economic association of different levels of integration depth and of different scope of the covered regulatory areas successfully operate in Eurasia. Only two of them - the EU and the EEU - have supranational regulatory bodies, while the others function as interstate ones. Most of the regional associations aim at eliminating trade barriers, creating free trade zones, and harmonizing technical, customs, tariff, and non-tariff regulations. However, in practice, the creation of educational centers does not always lead to overcoming contradictions between states and reducing transaction costs in interstate interaction (primarily economic). The rapid development of various multilateral formats and institutions in Eurasia over the past two decades is now rather a source of conflict. Regional cooperation formats are actively used by states to stabilize the surrounding space - in a situation of weakening of educational centers of global regulation. To a significant extent, such a policy is typical for regional players who claim to be independent centers of power amidst relative fall of global liberal order and its backing up state in the face of the United States, which usually are the initiators of creation of such formats [4, pp. 82-96]. Nevertheless, in the competition between major powers, educational centers and formats proposed by them are often considered by their opponents as hostile. Recently, a number of researchers even bring up the phenomenon of "institutional weapons" that allow states to use the promotion of these institutions and norms as an instrument of international political struggle [7].

Along with basic regional associations (customs unions and free trade zones) formed to create common markets for goods, labor and capital, as well as services, there are a number of regional initiatives aimed at 
stimulating investment activity, implementing joint investment projects, including large-scale programs for development of transport and energy infrastructure. International banks and development institutions operating both within the relevant regional associations and throughout the Eurasian continent play vital role in supporting such integration initiatives. At the same time, a distinctive feature of the Greater Eurasian Partnership is the growing role of regional integration associations of the Eurasian continent, such as the EAEU, ASEAN, the SCO, and the EU.

According to the Minister of Trade of the EEC V. O. Nikishina, in the current realities of the world economy and politics, China is an "organic partner" for the EAEU at the beginning of the "deployment" of the Great Eurasian Partnership. "The integration of the EAEU and the Chinese project "One Belt One Road" will become not just an important part of it, but, as we hope, the engine, the "pilot project" of the whole idea" [8]. Today, it is advisable to consider the idea of the GEP in terms of the content of the GEP concept, as well as promoting this initiative among international partners and contacts through the EAEU.

Currently, there is no official concept for the formation of GEP. This idea is based on the speeches and ideas of Russian President Vladimir Putin, which are being developed by Russian Foreign Minister Sergey Lavrov and a number of other official representatives of the Russian government, experts and representatives of the business community. Moreover, over time, the very idea of the GEP evolves, ranging from a "network of bilateral and multilateral trade agreements" to "the combination of the potentials of various integration projects" and "the basis for the formation of a more harmonious technological and institutional world order" with the inclusion of both Asian and European countries.

Returning to the idea of GEP at the final plenary session of the XIII annual meeting of the Valdai Discussion Club on October 27, 2016, Vladimir Putin once again noted: "Russia stands for the harmonization of regional economic formats based on the principles of transparency and respect for each other's interests. This is how we are building the activities of the Eurasian Economic Union, and we are negotiating with our partners, including on the connection with the Silk Road Economic Belt project being implemented by China. We hope that this will allow us to form the Great Eurasian Partnership... To implement this idea, a five-plus-one dialogue on the agreement on trade and economic cooperation between all participants in this process has already been launched" [9]. 
Vladimir Putin and other Russian representatives also spoke about the need to create the Great Eurasian Partnership between the EAEU and other countries, including China, India, Iran, Pakistan and CIS partners, at the Eastern Economic Forum in Vladivostok in September 2016.

The scientific article of the RAS academician, Doctor of Economics, S. U. Glazyev called "The Great Eurasian Partnership: creating a new world" presents conceptual approaches in the most detailed way. In this article professor Glazyev points out: "Searching for the alternative way of economic integration within the scope of President Putin's initiative to establish GEP Russia can rely on PRC as the most eminent "Asian tiger" of SEA. During the last economic forum in Vladivostok, the leader of China $\mathrm{Xi}$ Jinping proved the boost of centripetal tendencies between the mutually interested states of the continent by outlining terminologically and ideologically the key concept of the future integration grouping - the Northeast Asian Economic Circle. From the rostrum of the World Economic Forum 2018 it was spoken out this way: "We should raise the level of interconnection of transnational infrastructure in the sphere of trade and investment liberalization and facilitation, furthermore, it is vital to foster market liquidity along with capital and technology transfer, to optimize resourcing and industrial structure, to build an open regional economy together and form the Northeast Asian economic circle... We are ready to study the opportunities of cooperation development in other multilateral and subregional formats in order to initiate more practical projects for the benefit of the region's peoples" [10, pp. 18-20]. All members of the process must consider the specific socio-economic and political background in the Eurasian states, unconditionally respect the national sovereignty of each state, follow the principle of non-interference in its internal affairs and save the diversity of economic and political culture as a necessary condition for fair competition of national jurisdictions and cooperative development based on a combination of competitive advantages. GEP is to be formed through the flexible system of legal provisions, joint projects, and institutions, which take into account the interests of all members and have a voluntary nature of cooperation.

The idea of GEP is actively promoted by government officials as well as by business and expert communities. For instance, on March 14, 2019 while giving to "Zvezda" media group the interview headlined "The Great Eurasian Partnership will build a foundation for a more harmonious technologic and institutional world order" S.U. Glazyev pointed out that "long-lasting peace and Eurasia's prosperity is the aim of creating such a 
partnership (GEP). Some issues had to be solved to achieve this goal. Namely, we need to establish a preferential regime of trade and economic cooperation; develop continental, transport, information, and energy infrastructure; learn to combine national development plans with the harmonization of international technological and manufacturing cooperation and shift to a fair system of monetary relations. In addition to this, we should reach the cessation of current armed conflicts and prevent the new ones" [11].

According to Russian Foreign Minister Sergey Lavrov in an interview with the Chinese newspaper Global Times on May 28, 2020, "it is essential to jointly search for new growth points that can help overcome the general downturn. The contribution to this work on a global scale can be the combination of the potentials of various integration projects that are being implemented in the great Eurasian spaces. This is what the initiative to form the Greater Eurasian Partnership based on the principles of international law and transparency, open to all countries of this vast continent, including the members of the EurAsEC, the SCO, and ASEAN, is aimed at. Its systematic implementation will not only strengthen the positive economic interconnectedness, increase the competitiveness of all participants, but also become a solid foundation for building a space of peace and stability from Lisbon to Jakarta" [12]. Meaningfully, the GEP can represent a network of key regional economic associations and the largest national economies of Eurasia, linked by a flexible system of international legal norms, transport and logistics, energy, telecommunications and financial infrastructures, joint projects and institutions that combine national development plans with the harmonization of international production and technological cooperation and strive to promote a fair system of monetary and financial relations, mutual opening of access to the markets of goods and services through the formation of preferential treatment of trade and economic cooperation.

The GEP aims to transform Eurasia into a zone of peace, prosperity and cooperation. Its result provides for the solution of the tasks of developing the mainland transport, energy and information infrastructure, the transition to a fair system of monetary and financial relations, the combination of national development plans and the harmonization of international production and technological cooperation, the mutual opening of access to the markets of goods and services through the creation of preferential treatment of trade and economic cooperation. It is important to develop the GEP concept in the context of determining a certain balance between 
structural economic projects in the region (the Chinese "One Belt One Road" initiative, the Northern Sea Route, the Trans-Siberian Railway, etc.) and possible other projects that will be initiated in the future.

By now minding the active promotion of the OBOR topic in the expert community, it may seem that the process of forming the GEP is closely linked to the development of the "One Belt One Road" initiative. This approach is not consistent with the goals and universal nature of GEP. The combination of the platforms of the Greater Eurasian Partnership and the concept of linking the EAEU of the "One Belt One Road" initiative also occurs because the supervision of these topics in Russia is entrusted to one official. It is important to note that Russia has not officially joined the "One Belt One Road" project and is considering this initiative in the context of integration with the EAEU. The idea of building the EAEU and the Chinese initiative "One Belt One Road" was reflected in the comprehensive Agreement on trade and economic cooperation between the EAEU and China signed in May 2018 (entered into force on October 25, 2019) and the Agreement on the Exchange of Information on Goods and Vehicles of International Transport Transported across the Customs Borders of the EAEU and the PRC (has not yet entered into force), that was concluded in June 2019.

GEP is broader both geographically and by content. Conceptually, the idea of the Greater Eurasian Partnership involves covering the entire continent, including its Asian and European parts, as well as developing the idea of creating a common economic space from Lisbon to Vladivostok, which is familiar to Europeans. Thus, the identification of the "One Belt One Road" initiative and the idea of linking the construction of the EAEU and this initiative as the core of the entire GEP is impractical, since it does not fully reflect the objective economic processes taking place in Eurasia. This leads to the conclusion that the level of interaction between the member states of the Union and the global economic locomotive of the region - China - is quite high. There is a large degree of economic orientation of Belarus, Kazakhstan and Kyrgyzstan towards China. On the background of specific financial and economic bonuses from cooperation with China, the possible effect of the GEP for individual member states of the Union is not yet so obvious.

Conclusions. Thus, taking into account the specifics of the content of the Greater Eurasian Partnership, the question arises about the possibility of a clear formulation of approaches to the architecture of this idea, as well as the role of the EAEU in this system. The main conclusions about the at- 
tractiveness of this idea for international partners should be based on a substantive and thorough expert analysis. It seems that the efforts of the EAEU countries to write it in a reasonably acceptable period of time is extremely problematic. The outline of this concept, prepared by Russia, could be the first step towards a public dialogue on this topic, defining the further dialogue discussed in a broad format. The various formats of interaction between the states of the Greater Eurasian Partnership, if necessary and if there is a request from the partners in Eurasia, can be implemented in the relevant framework documents, but at this point of time it is too early to talk about this.

\section{References}

1. Glyants M. Kitaiskaya initsiativa «odin poyas - odin put'»: chto mozhet sdelat' «brend». Problemy postsovetskogo prostranstva. [China's Belt and Road Initiative: What a Brand Can Do. Problems of the post-Soviet space] 2017; 4 (1): 8-19. (In Russ.).

2. Ministry of Foreign Affairs of Japan (2015) Announcement of "Partnership for Quality Infrastructure: Investment for Asia's Future”. 21 May. URL: http://www.mofa.go.jp/policy/oda/page 18_000076.html. (accessed: 22.10.2021).

3. Informatsionnoye agentstvo TASS // Putin prizval sozdat' bol'shoye Yevraziyskoye partnerstvo. Peterburgskiy mezhdunarodnyy ekonomicheskiy forum 2016 [TASS news agency // Putin called for a great Eurasian partnership. St. Petersburg International Economic Forum 2016]. URL: http://tass.ru/pmef-2016/article/3376295. (accessed: 22.10.2021) (in Russ.).

4. Nye J., Keohane R. (1971) Transnational Relations and World Politics: An Introduction. International organization, vol. 25, no 3, pp. 329-349.; Gilpin, 1983 - Gilpin R. (1983) War and Change in World Politics. Cambridge University Press.

5. Waltz K. (1979) Theory of International Politics. New York: McGraw-Hill Higher Education.; Ikenberry, 2001 - Ikenberry G.J. (2001) After victory: Institutions, Strategic Restraint, and the Rebuilding of Order After Major Wars. Princeton University Press.

6. Novikov D. P. "Bol'shoye yevraziyskoye partnerstvo: vozmozhnoye vliyaniye i interesy Rossii" Vestnik mezhdunarodnykh organizatsiy: obrazovaniye, nauka, novaya ekonomika, ["Great Eurasian Partnership: Potential Regional Influence and Interests of Russia” Bulletin of International Organizations: Education, Science, New Economy] Vol. 13, net. 3, 2018, s. 82-96. (In Russ.).

7. Leonard, 2016 - Leonard Mark (2016) Connectivity Wars. URL: http://www.ecfr.eu/page//Connectivity_Wars.pdf. (accessed: 22.10.2021).

8. Ofitsial'nyy sayt YEEK // Ministr YEEK Veronika Nikishina: «Bol'shoye Yevraziyskoye partnerstvo dolzhno uchityvat' interesy vsekh igrokov na prostranstve Yevrazii» [Official website of the EEC // EEC Minister Veronika Nikishina: "The Great Eurasian Partnership should take into account the interests of all players in the Eurasian space"]. URL: http://www.eurasiancommission.org/ru/ nae/news/Pages/10-12-2019-5.aspx. (accessed: 22.10.2021) (in Russ.).

9. Ofitsial'nyy sayt Prezidenta RF // Vladimir Putin prinyal uchastiye v itogovoy plenarnoy sessii XIII yezhegodnogo zasedaniya Mezhdunarodnogo diskussionnogo kluba «Valday». Tema zasedaniya $\mathrm{v}$ etom godu - «Budushcheye nachinayetsya segodnya: kontury zavtrashnego mira» [Official site of the President of the Russian Federation // Vladimir Putin took part in the final plenary session of the XIII annual meeting of the Valdai International Discussion Club. The theme of this year's meeting is "The future begins today: the contours of tomorrow's world"]. URL: http://kremlin.ru/events/president/news/53151. (accessed: 22.10.2021) (in Russ.).

10. Glazev S. Y. "Bol'shoye evraziyskoye partnerstvo: sozidaya novyi mir" Evraziyskaya integratsiya: ekonomika, pravo, politika, [The Great Eurasian Partnership: Building a New World" Eurasian Integration: Economics, Law, Politics] no. 1 (27), 2019, s. 18-20. (In Russ.). 
11. Setevoye izdaniye «Yezhenedel'nik «ZVEZDA »// Sergey Glaz'yev:« Bol'shoye yevraziyskoye partnerstvo sozdayet osnovu dlya formirovaniya boleye garmonichnogo tekhnologicheskogo i institutsional'nogo miroustroystva» Setevoye izdaniye «Yezhenedel'nik ZVEZDA» // Sergey Glaz’yev:«Velikoye yevraziyskoye partnerstvo sozdast osnovu dlya formirovaniye boleye garmonichnogo tekhnologicheskogo i institutsional'nogo miroustroystva»]. URL: 'https://zvezdaweekly.ru/ news/t/2019313107-2Yqsz.html. (accessed: 22.10.2021) (in Russ.).

12. Ofitsial'nyy sayt MID RF // Stat'ya Ministra inostrannykh del Rossiyskoy Federatsii S.V.Lavrova o situatsii v mire v kontekste pandemii koronavirusa dlya kitayskoy gazety «Global Tayms» [Official website of the Russian Foreign Ministry // Article by the Minister of Foreign Affairs of the Russian Federation Sergey Lavrov on the situation in the world in the context of the coronavirus pandemic for the Chinese newspaper Global Times]. URL: https://www.mid.ru/ foreign_policy/news/-/asset_publisher/cKNonkJE02Bw/content/id/4139447. (accessed: 22.10.2021) (in Russ.).

Received: 08.09.2021.

About author: Ivantsov Aleksei Vasilyevich - applicant of Department of social policy and ideology Academy of Public Administration under the President of the Republic of Belarus, aliaskei.ivantsou@yandex.ru.

\title{
БОЛЬШОЕ ЕВРАЗИЙСКОЕ ПАРТНЕРСТВО: ЭКОНОМИЧЕСКИЕ ПЕРСПЕКТИВЫ ИНТЕГРАЦИИ В РАМКАХ ЕАЭС
}

\author{
А. В. ИВАНЦОВ \\ Академия Управления при Президенте Республики Беларусь, \\ г. Минск, Республика Беларусь
}

Аннотация. В данной статье анализируется текущее состояние и перспективы интеграционных объединений и форматов многостороннего экономического сотрудничества с точки зрения реализации инициативы Всеобъемлющего евразийского партнерства. Автор анализирует роль этой инициативы как инструмента российской политики и дает оценку ее потенциалу для укрепления международного сотрудничества в Евразии. В частности, анализируются возможности гармонизации ключевых проектов и инициатив в рамках ЕАЭС. В работе изучается потенциал крупнейших многосторонних форматов в Евразии как в экономической сфере - Всеобъемлющего регионального экономического партнерства, инициативы «Один пояс - один путь», Евразийского экономического союза и др. Отдельный акцент делается на возможности подключения России к многосторонним экономическим проектам в Евразии как локомотиву продвижения стратегических интересов, а также реализации потенциала ЕАЭС.

Делается вывод, что в экономической сфере Большой Евразии наблюдается институциональная перегруженность, вызванная существованием ряда параллельно развивающихся интеграционных инициатив и механизмов экономического сотрудничества. Исходя из вышесказанного, усиление ЕАЭС как институционального ядра Большой Евразии может стать основой для формирования нормативного мега-пространства. Однако совокупный экономический по- 
тенциал государств - участников ЕАЭС не позволяет Союзу быть крупнейшим экономическим полюсом и ведущим центром развития многосторонних институтов в Большой Евразии. Предполагается, что решением в данной задачи могло бы стать развитие Всеобъемлющего евразийского партнерства в сторону сопряжения ЕАЭС и ВРЭП - крупнейшего формата выработки правил международного экономического взаимодействия в Азии и формулирования конкретных предложений по выстраиванию системы взаимовыгодных отношений между крупнейшими игроками Евразии, в которую все заинтересованные государства будут вовлечены на взаимовыгодных условиях для укрепления международного сотрудничества.

Ключевые слова: Большое евразийское партнерство; ЕАЭС; ЕС, ВРЭП; Евразия; интеграция; «Один пояс - один путь»; Шанхайская организация сотрудничества.

\section{Библиографические ссылки}

1. Глазьев С. Ю. Большое евразийское партнерство: созидая новый мир // Евразийская интеграция: экономика, право, политика. 2019. №. 1 (27). С. 18-20.

2. Глянц М. Китайская инициатива «один пояс - один путь»: что может сделать «бренд» // Проблемы постсоветского пространства. 2017. № 4(1). С. 8-19.

3. Новиков Д. П. Большое евразийское партнерство: возможное региональное влияние и интересы России // Вестник международных организаций: образование, наука, новая экономика. 2018. Вып. 13. № 3. С. 82-96.

4. Nye J., Keohane R. Transnational Relations and World Politics: An Introduction // International organization. 1971. Вып. 25. № 3. С. 329-349.

5. Waltz K. Theory of International Politics. New York: McGraw-Hill Higher Education.; Ikenberry, 2001.

Дата поступления статьи: 08.09.2021.

Образец цитирования: Иванщов $A$. В. Большое евразийское партнерство: экономические перспективы интеграции в рамках ЕАЭС // Актуальные проблемы международных отношений и глобального развития. Минск, 2021. Вып. 9. С. 303-312. https://doi.org/10.33581/2311-9470-2021-9-303-312

Автор: Иванцов Алексей Васильевич - соискатель кафедры социальной политики и идеологии Академии управления при Президенте Республики Беларусь, aliaskei.ivantsou@yandex.ru. 